\title{
Komorbiditet kod ovisnika i tretmanske intervencije
}

\author{
Ksenija Butorac \\ Visoka policijska škola, Zagreb \\ $\square$ E-mail: kbutorac@fkz.hr
}

\author{
Lorena Rukav \\ "Moji dani", Udruga za prevenciju ovisnosti, pomoć ovisniku i povremenom \\ uzimatelju opojne droge i obitelji Đurmanec
}

Sažetak

Zlouporabom ilegalnih droga, ali i prekomjernim uzimanjem legalno propisanih psihofarmaka nastaju štetne posljedice povezane s ozbiljnim javnozdravstvenim problemima, što predstavlja ključno pitanje nacionalne i međunarodne politike suzbijanja ovisnosti o psihoaktivnim sredstvima. Istodobna pojavnost problematične konzumacije droga i psihičkih poremećaja nerijetko stvara težu kliničku sliku i pridružene socijalne teškoće u različitim područjima života osobe radi čega je neophodno usmjeravanje snaga i napora zajednice za njihovo rješavanje. S obzirom na gotovo neznatnu pozornost $\mathrm{i}$ relativno oskudne rezultate inozemnih, a osobito domaćih održivih empirijskih istraživanja, kao i općeprihvaćenih stajališta znanstvenika i stručnjaka u pogledu obrazaca, etiologije, dijagnostičkih instrumenata i modela dobre prakse u tretmanu komorbiditeta, cilj ovog rada je pružiti integrirani pregled dosadašnjih istraživanja s kritičkim osvrtom i preporukama uzimajući pritom u obzir slabosti i mogućnosti različitih sustava tretmana ovisnika s komorbidnim poremećajem. Između ostalog, u radu se razmatraju determinante odnosa između psihičkih poremećaja i poremećaja izazvanih zlouporabom droga kroz analizu rizičnih čimbenika. Rad sadrži sustavan pregled dosadašnjih istraživanja koja se odnose na obilježja pojedinih psihičkih poremećaja u komorbiditetu s problematičnom konzumacijom droga te kratki prikaz relevantnih dijagnostičkih instrumenata i modela tretmana za osobe s dualnim poremećajem. Dobiveni podaci ukazuju na znatnu zastupljenost komorbiditeta u ovisničkoj populaciji, a osobito unutar marginalnih skupina, kao i važnost sveukupne procjene bio-psiho-socijalnih obilježja korisnika tretmana. Vezano uz tretman komorbiditeta, teoretičari i praktičari se do danas nisu usuglasili u pogledu modela dobre prakse, bilo da je riječ o farmakološkom i/ili psihosocijalnom tretmanu. Međutim, rezultati novijih istraživanja ukazuju na potrebu provođenja integrativnog pristupa tretmanu koji podrazumijeva farmakološke i psihosocijalne intervencije. U cjelini gledano, istraživanja komorbiditeta kod ovisnika su nedostatna, a u Hrvatskoj gotovo i ne postoje, stoga postoji potreba za daljnjim istraživačkim naporima u ovom području radi poboljšanja provedbe postojećih preventivnih i tretmanskih smjernica.

Ključne riječi: komorbiditet, rizični čimbenici, dijagnostički instrumenti, modeli tretmana ovisnika

\section{Uvod}

Uporabom ilegalnih droga, ali i prekomjernim uzimanjem propisanih psihofarmaka, nastaju štetne posljedice povezane s ozbiljnim javnozdravstvenim problemima, što predstavlja ključno pitanje nacionalne i međunarodne politike. O težini problema govore i podaci Europskog centra za praćenje droga i ovisnosti o drogama (European Monitoring Centre for Drugs and Drug Addiction — EMCDDA, 2017) koji procjenjuje da je nešto više od 93 milijuna ljudi, odnosno preko četvrtine Europljana u dobi od 15 do 64 godine, tijekom života probalo drogu. Kod njene produljene uporabe 
događa se istodobna pojavnost ovisnosti i određenih psihičkih poremećaja — komorbiditet ili dualni poremećaj, što se očituje u težoj kliničkoj slici i pridruženim socijalnim teškoćama u različitim područjima života ovisnika radi čega je neophodno usmjeravanje snaga i napora za njihovo rješavanje. Općenito uzevši, najveća pozornost pridaje se endogenim posljedicama vezanim uz somatsko zdravlje ovisnika koje se odnose na krvne infekcije, među kojima su najpoznatije HIV i hepatitis C (EMCDDA, 2015). Navedene bolesti čine organizam ranjivijim i prijemčivijim na ostale bolesti somatske ili psihičke naravi, čime se cjelokupno zdravstveno stanje dodatno pogoršava. Ako se uz uporabu psihoaktivnih tvari pojavi i neki psihički poremećaj, ove se posljedice uvećavaju uzrokujući ozbiljne probleme i rizike koji mogu teško narušiti samostalni život osobe te utječu na višu prevalenciju samoubojstva, višestruku uporabu droga i lijekova, štetne učinke za nerođeno i novorođeno dijete, značajno povećane stope psihijatrijskih hospitalizacija i slično (EMCDDA, 2015). $S$ druge strane, egzogene posljedice obuhvaćaju okolinske čimbenike poput povećane stope rizičnih i antisocijalnih ponašanja, primjerice, nasilnog ili kriminalnog ponašanja do izdržavanja zatvorske kazne. Psihosocijalne posljedice mogu uzrokovati višu stopu nezaposlenosti i beskućništva, medicinske i financijske probleme te, u konačnici, lošu tretmansku prognozu i lošije tretmanske ishode. Uzevši sve navedeno u obzir, kod osoba s istodobnom prisutnošću ovisnosti i psihičkih poremećaja postoji povećani rizik za kronični niz problema koji vodi ka isključivanju iz društvene zajednice, pri čemu je tretman, vremenski i ekonomski gledano, zahtjevna investicija, a mogućnosti za oporavak su znatno smanjene. Navedeno ukazuje na neophodnost bavljenja ovom problematikom kako bi se smanjile ukupne štete (i troškovi) za društvo, a ovaj višedimenzionalni problem ujedno predstavlja i ozbiljan izazov za liječnike, pomažuće struke i donositelje javnih politika budući da se osobe kojima je potrebna pomoć često nalaze na marginama društva i stoga su pretežno nedostupne za prihvat i tretman.

S obzirom na gotovo neznatnu pozornost i relativni nedostatak rezultata inozemnih, a osobito domaćih održivih empirijskih istraživanja, kao i općeprihvaćenih stajališta znanstvenika i stručnjaka u pogledu obrazaca, etiologije, dijagnostičkih instrumenata i modela dobre prakse u tretmanu komorbiditeta, cilj ovog rada je pružiti integrirani pregled dosadašnjih istraživanja s kritičkim osvrtom i preporukama uzimajući pritom u obzir slabosti i mogućnosti sustava tretmana ovisnika s komorbidnim poremećajem.

\section{Određenje komorbiditeta i mehanizmi u objašnjavanju komorbiditeta ovisnosti i psihičkih poremećaja}

Proučavanje utjecaja komorbiditeta na ovisnika tijekom vremena je bilo otežano zbog nedostatka konsenzusa u pogledu definicije i mjerenja koncepta. U tom smislu Svjetska zdravstvena organizacija (WHO, 2010) dvojne ili dualne dijagnoze definira kao zajedničko pojavljivanje poremećaja vezano uz uporabu psihoaktivnih tvari i drugog psihičkog poremećaja kod pojedinca. Slično tome, pojavu istodobne prisutnosti dvaju ili više psihičkih poremećaja, pri čemu je jedan od njih ovisnost, Europski centar za praćenje droga i ovisnosti (EMCDDA, 2015) naziva komorbiditet ili dualni poremećaj. Uz dualnu dijagnozu u praksi se koristi i termin komorbiditet, kojeg Valderas i sur. (2009) definiraju kao prisutnost više od jednog različitog stanja kod osobe od kojih se jedno odnosi na ovisnost. S druge strane, Bayliss, Edwards, Steiner i Main (2008) koriste pojam multimorbidnosti koji označava pojavu višestrukih kroničnih ili akutnih bolesti i medicinskih 
stanja kod pojedinca. Tako su dualni poremećaji primjer multimorbidnosti kod koje koegzistiraju dva različita poremećaja - psihički poremećaj i ovisnost. Tijekom posljednja tri desetljeća pojam dualne dijagnoze postao je standardiziran te se počeo koristiti u registrima od 1989. godine za odrasle osobe kod kojih su istovremeno prisutni teška psihička bolest i poremećaj vezani uz ovisnost (Drake i Wallach, 2000). Pozitivan aspekt formalnog priznanja postojanja dualne dijagnoze odnosi se na stanovito pojednostavljivanje složenog problema na medicinski pojam kojim se podrazumijeva prihvaćanje i liječenje problema ovisnosti te je od 1990. godine službeno priznata povezanost između ovisnosti i brojnih negativnih ishoda kod osoba s dualnim poremećajem (Drake i Brunette, 1998; prema Drake i Wallach, 2000).

lako postoje brojni dokazi koji podupiru snažnu poveznicu između psihičkih poremećaja i ovisnosti, priroda njihove povezanosti vrlo je složena. Ona uvelike ovisi o specifičnom psihičkom poremećaju poput depresije, anksioznog poremećaja, psihoze i slično, kao i o vrsti droge koju pojedinac uzima, primjerice, kanabisu, opijatima ili psihostimulativnim drogama. $U$ tom pogledu, postoje četiri hipoteze koje međusobno nisu isključive u objašnjavaju etiološke i neurobiološke komponente komorbiditeta.

Prva hipoteza tvrdi kako kombinacija ovisnosti i drugog psihičkog poremećaja može predstavljati dva ili više neovisna stanja. Tako se pojava komorbiditeta objašnjava kroz posljedično djelovanje predisponirajućih čimbenika poput stresa, genetskog utjecaja i slično, koji utječu na rizik za razvoj multiplih stanja. Brady i Sinha (2005) ističu kako ovisnost i psihički poremećaji mogu imati različito izraženu simptomatologiju unatoč sličnim, već postojećim neurobiološkim abnormalnostima. Istraživanjima u području neuroznanosti pokazalo se kako biološki i genetski čimbenici igraju ključnu ulogu vezanu uz vulnerabilnost pojedinca za razvoj ovih poremećaja. U tom pogledu ovisnost i drugi psihijatrijski poremećaji, uključujući psihološka i biološka obilježja te stanja osobe, vjerojatno pripadaju razvojnim poremećajima (EMCDDA, 2015, 18). Ovom hipotezom ovisnost se objašnjava kao ponašajni poremećaj (vezan uz različita psihoaktivna sredstva) koji se javlja kod osoba vulnerabilnog fenotipa. Naime, sve psihoaktivne tvari s potencijalom za njihovu zlouporabu utječu na endogeni sustav poput opijatnog, nikotinskog ili dopaminergičkog sustava. Stoga, naslijeđeni ili stečeni nedostaci u ovim neurobiološkim sustavima mogu objasniti ovisničko ponašanje i druge psihijatrijske simptome.

Druga hipoteza navodi kako prethodna prisutnost psihičkog poremećaja predstavlja rizični čimbenik za razvoj komorbiditeta. Khantzian (1985) u tom smislu zastupa stajalište da se ovisnost javlja kao rezultat pokušaja suočavanja i nošenja s problemima vezanim uz psihičke poremećaje poput socijalne fobije, psihoze i poslijetraumatskog stresnog poremećaja. Stoga, kod osoba s psihičkim poremećajima otežano se mogu predvidjeti negativne posljedice, npr. kod manije i antisocijalnog poremećaja ličnosti (EMCDDA, 2015). S druge strane, prisutnost psihičkog poremećaja može negativno djelovati na pojedinca time što povećava rizik teške i ponavljajuće uporabe droga, primjerice kod kokaina. Posljedično se može razviti i ovisnost koja se može nastaviti čak i kada je već postojeće psihičko stanje pravilno tretirano ili je u remisiji (Moeller i sur., 2001).

Treća hipoteza tvrdi kako ovisnost može biti okidač za razvoj drugog psihičkog poremećaja tako što se psihički poremećaj tada nastavlja razvijati u neovisnom smjeru. Jednako tako, uporaba droge može predstavljati okidač i za osnovni dugoročni poremećaj. Navedeno vjerojatno predstavlja 
najvažniju poveznicu između uporabe marihuane i shizofrenije jer je otprije poznato kako uporaba kanabisa kod vulnerabilnih adolescenata može pridonijeti razvoju psihoze koja kasnije vodi ka neovisnoj bolesti (Radhakrishnan, Wilkinson i D'Suoza, 2014). U ostalim slučajevima opetovana uporaba droge kroz neuroadaptaciju može dovesti do abnormalnih bioloških promjena i posredovati kod pojavnosti psihičkog poremećaja (Bernacer i sur., 2013).

Posljednja, četvrta, hipoteza odnosi se na psihoaktivnom tvari induciran poremećaj. Navodi se kako je privremeni psihički poremećaj nastao kao posljedica intoksikacije, sa ili bez simptoma apstinencijske krize i kao posljedica uporabe određene tvari. Naime, privremeni psihički poremećaj može nastati kao posljedica uporabe određene droge poput psihostimulativnih i halucinogenih droga ili, pak, kao posljedica apstinencijske krize koja je obilježena pojavom depresivnih simptoma nakon prestanka korištenja droga. Rezultati novijeg istraživanja o sličnim obrascima komorbiditeta i rizičnim čimbenicima kod ovisnika te onih koji imaju neovisne psihičke simptome (nisu inducirani drogom), ukazuju kako navedena dva poremećaja mogu imati zajednički ishodišni etiološki čimbenik (Blanco i sur., 2012).

\section{Epidemiološki podaci o prevalenciji dualne dijagnoze u Europskoj uniji}

Zlouporaba droga u EU danas obuhvaća puno širi spektar tvari u odnosu na desetljeće ranije. U tom pogledu, osim kanabisa, heroina, amfetamina i drugih već poznatih vrsta, na ilegalnom je tržištu široka ponuda novih psihoaktivnih tvari. Razvojem tehnologije i promjenama na tržištu droga dolazi do pojave novih načina proizvodnje i krijumčarenja droga i uspostave novih putova prodaje uz posredovanje internetskog tržišta. Ovakav trend znatno utječe na raširenost i povećanu incidenciju uporabe droga. EMCDDA (2017) procjenjuje da je tijekom 2016. godine 18,7 milijuna mlađih odraslih osoba u dobi od 15 do 34 godine uporabilo droge pri čemu broj muškaraca dvostruko premašuje broj žena. Navedeni podaci ukazuju na značajno visoku uporabu droga neovisno o kojoj vrsti droge je riječ. Primjerice, podaci vezani uz prevalenciju komorbidnih dijagnoza u općoj populaciji u Danskoj, Finskoj, Poljskoj, Engleskoj i Škotskoj pokazuju da 43 do 120 osoba na 100 000 stanovnika zadovoljava kriterije za dijagnozu komorbiditeta sa zlouporabom alkohola ili psihoaktivne tvari (Baldacchino i sur., 2009). Europski centar za praćenje droga i ovisnosti o drogama (EMCDDA, 2015) navodi da se prevalencija bipolarnog poremećaja u komorbiditetu s ovisnošću kreće u rasponu od $40 \%$ do $60 \%$ u Europskoj uniji.

Klinička istraživanja u ustanovama mentalnog zdravlja u Njemačkoj utvrdila su da se prevalencija shizofrenije kod ovisnika kreće od 27 \% do 47 \% (Hermle i sur., 2013, 315). EMCDDA (2013, 8) navodi da je u Hrvatskoj kod $21 \%$ ovisnika u tretmanu dijagnosticiran komorbiditet s prevalencijom poremećaja ličnosti i poremećaja u ponašanju oko $20 \%$, dok u Finskoj više od $50 \%$ ovisnika u tretmanu ima dijagnosticiranu zlouporabu droga s depresivnim poremećajem. U Nizozemskoj je ustanovljeno da 84 \% ispitanika ima komorbiditet pri čemu su najzastupljeniji psihotični, depresivni i anksiozni poremećaj (EMCDDA, 2013, 8). Nadalje, Rodriguez-Llera i sur. $(2006,53)$ su kod ovisnika o heroinu utvrdili kako $67 \%$ ispitanih ima prevalenciju cjeloživotnog komorbiditeta psihičkih poremećaja pri čemu su najučestaliji antisocijalni i granični poremećaj ličnosti. Rezultati istraživanja Casares-Lopeza i sur. (2011) u zatvorskoj populaciji pokazali su kako čak 85 \% španjolskih zatvorenika s ovisnošću ima komorbiditet, dok Palijan, Muzinić i Radeljak $(2009,429)$ izvještavaju 
o udjelu komorbiditeta kod nasilnih prijestupnika od $50 \%$ do $80 \%$. S druge strane, Aichhorn $\mathrm{i}$ sur. (2008) su istraživali beskućnike mlađe životne dobi u Austriji te utvrdili da $80 \%$ ispitanika ima psihičke poremećaje, od čega njih 65 \% ima komorbiditet s ovisnošću. U Francuskoj je utvrđeno da $95 \%$ ovisnika beskućnika ima poremećaj ličnosti (Combaluzier, Gouvernet i Bernoussi, 2009, 451).

Općenito uzevši, očito je da su podaci o prevalenciji psihičkih komorbiditeta kod ovisnika vrlo heterogeni ovisno o ispitivanoj ciljnoj populaciji i metodološkim specifičnostima samih istraživanja. Međutim, unatoč metodološkim razlikama, pronađena su određena zajednička obilježja vezana uz vrste psihičkih poremećaja u komorbiditetu s ovisnošću. U tom smislu najzastupljeniji psihički poremećaji su depresivni i anksiozni poremećaj, nakon čega slijede poremećaji ličnosti i psihotični poremećaj. Također je razvidno kako postoji visoki stupanj prevalencije komorbidnih dijagnoza kod ovisnika (oko $50 \%$ ), stoga budući rad prvenstveno treba usmjeriti prema podizanju svijesti o njihovoj rasprostranjenosti te potrebi veće dostupnosti tretmanskih intervencija, što bi u konačnici dovelo do smanjivanja udjela oboljelih osoba.

\section{Specifični rizični čimbenici za nastanak i razvoj komorbiditeta ovisnosti i psihičkih poremećaja}

Rizični čimbenici odnose se na stanja ili ponašanja kojima se povećava vjerojatnost negativnih ishoda na zdravstvenom i socijalnom planu osobe. Rizične čimbenike za razvoj komorbiditeta možemo promatrati s dva gledišta: individualnog i socijalnog uzimajući pritom u obzir čimbenike iz okruženja. Interakcijom ovih faktora i ovisnosti dolazi do prijelaza od povremene, vremenski isprekidane uporabe droga do redovite uporabe i ovisnosti. Time se pokreće mehanizam prijelaza od zlouporabe ka ovisnosti o psihoaktivnim tvarima, što ujedno predstavlja i rizični čimbenik za ponovni početak uporabe nakon završetka tretmana.

U kategoriji individualnih rizičnih čimbenika valja istaknuti kako ona obuhvaća više različitih elemenata kao što su genetsko nasljeđe i pripadajuća mu vulnerabilnost, spol, dob, osobine ličnosti, temperament, podražljivost organizma, emocionalna obilježja, prisutnost psihičkih poremećaja i slično. Svi elementi unutar ove kategorije rizičnih čimbenika smatraju se važnima u pojavi komorbiditeta, no, do sada su najveću pozornost privukli genetski rizični čimbenici. U tom pogledu Kendler i sur. (2003a) navode kako je većina promatranih tipova komorbiditeta pod utjecajem genetskih čimbenika te $85 \%$ komorbiditeta kod zlouporabe kanabisa ili kokaina proizlazi iz genetskih predispozicija osobe. Kendler i sur. (2003b) temeljem rezultata istraživanja navode kako genetski čimbenici imaju snažan utjecaj na obrazac komorbiditeta koji rezultira istovremenom pojavom dvaju čestih klastera internalizirajućih i eksternalizirajućih poremećaja. Nadalje, epidemiološke studije obitelji i blizanaca ukazuju na doprinos gena pojavi vulnerabilnosti za razvoj ovisnosti, te procjenjuju da nasljeđe u tom kontekstu ima $30 \%$ do $60 \%$ udjela (Kreek i sur., 2005). Istraživanje Lynskey i sur. (2004; prema Agrawal i Lynskey, 2014) na jednojajčanim blizancima ispitivalo je povezanost između početne uporabe kanabisa i razvoja ovisnosti o njemu, depresije te suicidalnih ideja i pokušaja. Ispostavilo se da su individualna iskustva poput rane izloženosti traumatskim iskustvima i početak uporabe kanabisa prije 17-te godine povezani s pokušajima samoubojstva, dok je zajednička genetska podloga povezana s ranom uporabom kanabisa i depresijom. U ovom slučaju kanabis se promatra kao okolinski okidač genetske osjetljivosti za npr. psihotičnu dimenziju bolesti (interakcija gena i okoline). Tako studija Caspija i sur. 
(2005; prema Agrawal i Lynskey, 2014, 361) pokazuje da interakcijom gena (varijacija gena koji kodira catechol-o-methyltransferase - COMT) i okoline dolazi do veće vjerojatnosti za pojavnost psihotičnih obilježja u odrasloj dobi kod osoba koje su konzumirale kanabis u adolescenciji. Cantao i sur. (2015) navode kako postoje slučajevi u kojima osoba započne s uporabom droga, no interakcijom genetskih predispozicija, psihoaktivne tvari i društvenih rizičnih čimbenika dolazi do razvoja psihičkih poremećaja. Iz navedenog proizlazi kako genetska obilježja pojedinca imaju stanovitu ulogu u razvoju komorbiditeta, međutim, potrebno ih je promatrati u odnosu s drugim osobnim i čimbenicima okruženja.

Istražujući poveznicu između dobi i komorbiditeta s ovisnošću, Zammit i sur. (2011) su proveli longitudinalnu studiju na uzorku od 14.062 djece rođene 1991. i 1992. godine i njihovih roditelja te utvrdili da je uporaba kanabisa u dobi od 14-te godine povezana s psihotičnim simptomima u dobi od 16 godina. Horwood i sur. (2012; prema Agrawal i Lynskey, 2014) nalaze da je učestala uporaba kanabisa povezana s umjereno teškom depresijom, osobito u doba adolescencije, dok van Ours i sur. (2013) navode kako je navedeni modalitet uporabe kanabisa povezan sa suicidalnim idejama, osobito kod mladića. Prema tome, iako nema konkretnih podataka o povezanosti između određene dobne skupine i komorbiditeta, prema dosadašnjim saznanjima evidentno je kako raniji ulazak u svijet ovisnosti, osobito u adolescenciji, predstavlja rizik za razvoj dijagnoze psihičkog poremećaja u komorbiditetu s ovisnošću.

Kognitivno funkcioniranje pojedinca predstavlja još jednu od sastavnica individualnih obilježja koje mogu potaknuti rizik za početak i kontinuiranu uporabu droga. Naime, kognitivno funkcioniranje u ovom kontekstu odnosi se na inhibiciju odgovora (voljno inhibiranje automatskih odgovora), radno pamćenje i pažnju. Sofuoglu i sur. (2013) navedene elemente ističu kao značajne za pojavu komorbiditeta ovisnosti i psihičkih poremećaja poput ADHD-a i depresije što potvrđuju i druga istraživanja i metaanalize (Scott i sur., 2007; Jovanovski, Erb i Zakzanis, 2005; prema Sofuoglu i sur., 2016). Međutim, kako su istraživanja u ovom području nedorečena i nedostatna, potrebne su longitudinalne studije koje će objasniti promjene u kognitivnim funkcijama kod ovisnosti u komorbiditetu s psihičkim poremećajem.

Sljedeće važno područje odnosi se na obilježja ličnosti. Do sada su brojne studije ukazale na činjenicu da se ovisnici razlikuju po osobnim obilježjima u koje ubrajamo impulzivnost, traženje uzbuđenja ili žudnju za uzbuđenjima te sklonost ka rizicima i skretanju od društvenih normi (Butorac, 2010). Stoga, u kontekstu dualnog poremećaja poznavanje ključnih obilježja ličnosti za pojavu ovisnosti može imati odlučan značaj u istraživanjima njihove povezanosti i utjecaja na razvoj psihičkih poremećaja. U tom pogledu neke studije pokazuju kako spomenute karakteristike ličnosti vode ka uzimanju alkohola i droga kako bi se na taj način kontrolirali komorbidni poremećaji ličnosti (Butorac, 2010). Istraživanjem osoba s komorbiditetom ovisnosti i psihičkih poremećaja utvrđena je češća prisutnost emocionalne nestabilnosti, introvertiranosti, nepovjerenja (Wilson, 1987) i sklonosti traženju uzbuđenja u odnosu na kontrolnu skupinu (Allen i sur., 1998.; Fisher i sur., 1998.; Graham i Strenger, 1988.; prema Antičević, Jokić-Begić i Britvić, 2012).

Wilsey i sur. (2008) ispitivali su depresiju, anksiozni poremećaj, poslijetraumatski stresni poremećaj (PTSP), panične napadaje i poremećaje ličnosti na uzorku od 113 ovisnika o opijatima. Utvrđena je statistički značajna povezanost između depresije, anksioznosti i paničnog poremećaja s ovisnošću. Nastavno, istraživanjem komorbiditeta ovisnosti o heroinu i anksioznosti, te depresije 
i suicidalnosti utvrđena je pozitivna povezanost s distimijom, beznađem, anksioznošću, ciklotimijom i podražljivim temperamentom (lliceto i sur., 2010). Ball $(2005,87)$ je utvrdio da su zlouporaba droga i konstelacija dezinhibicijskih crta ličnosti povezane s iskušavanjem droga u ranoj dobi, istovremenim uzimanjem više droga, kroničnim/teškim oblikom ovisnosti, poremećajem ponašanja i antisocijalnim poremećajem, nasiljem i rizičnim ponašanjem vezanim uz HIV, psihijatrijskim simptomima, poremećajem raspoloženja, pokušajima samoubojstva, obiteljskom patologijom i ranim napuštanjem škole. Uz navedeno, značajan element koji može pridonijeti početku uporabe droga odnosi se na osjećaj nelagode izazvane simptomima već prisutnih psihičkih poremećaja poput depresije. Naime, Cantao i sur. (2015) navode da pojedinci mogu započeti s uporabom droga kako bi umanjili simptome depresije te takva uporaba s vremenom može prerasti u ovisnost. Iz navedenog se može ustvrditi kako neke osobine imaju istaknutu ulogu rizičnih čimbenika za pojavu ovisnosti i pridruženog psihičkog poremećaja te da je prilikom procjene ovisnika na njih potrebno obratiti pozornost.

Razlike po spolu u odnosu na zastupljenost pojavnih oblika uporabe psihoaktivnih tvari te komorbiditeta i njegova tretmana objašnjavaju se biološkim i psihosocijalnim razlikama između muškaraca i žena (Becker i Hu, 2008). Naime, iako su muškarci skloniji zlouporabi psihoaktivnih tvari (Brady i Randall, 1999), žene su osjetljivije na njihove učinke u početnom stadiju razvoja ovisnosti o alkoholu i drogama. Nadalje, kod žena je prisutna viša stopa recidiva i komorbidnih poremećaja, češće se javljaju u tretman te teže ustrajavaju u održavanju apstinencije. Kad je uspiju uspostaviti, imaju veći broj psihičkih simptoma poput anksioznosti i depresije (Brady i sur., 1993).

Uz individualne rizične čimbenike, značajnu ulogu u razvoju komorbiditeta s ovisnošću imaju i rizični čimbenici u društvenom okruženju uključujući i one koji su vezani uz samu psihoaktivnu tvar. Neki od njih odnose se na obiteljsko okruženje, prisutnost stresnih/traumatskih životnih događaja, kemijski sastav droga i slično. Naime, Klein i Riso (1993, prema Green i sur., 2012) zaključuju kako osobe s komorbiditetom doživljavaju veću razinu stresa i dobivaju manju podršku u odnosu na one koji imaju samo jednu bolest. Ispitivanjem kanabisa otkriveno je da njegov farmakološki sastav povećava rizik za razvoj komorbiditeta ovisnosti i psihičkih poremećaja. Primjerice, uporabom THC-a (psihoaktivne komponente kanabisa) dolazi do trajnih promjena u regijama mozga koje mogu uzrokovati pojavu psihotičnih simptoma i psihoza (Bossong i sur., 2014). Povrh toga, istraživači navode kako prilikom razmatranja razvojnog puta komorbiditeta treba uzeti u obzir i utjecaj društvenih čimbenika u širem smislu. Kenkel, Mathios i Pacula (2001) navode kako ekonomska dostupnost i privlačnost određenih psihoaktivnih sredstava u pravilu dovodi do njihove povećane uporabe. Tako i ranije studije ističu marihuanu i alkohol kao ekonomski dostupne i nerijetko socijalno poželjne, a Chaloupka i Laixuthai (1997) zaključuju kako je potražnja za alkoholom niža u državama koje su dekriminalizirale marihuanu. S druge strane, Pacula (1998) navodi kako se marihuana i alkohol, ekonomski gledano, uzajamno nadopunjuju tako što se obje tvari često zajedno konzumiraju, a povećanje cijene jedne dovodi do pada uporabe obje tvari. Iz navedenog je razvidan znatan utjecaj cijena psihoaktivnih sredstava na tržištu na povećanje, odnosno smanjenje njihove uporabe. Stoga se može ustvrditi kako varijacije po tipu droge i trendovi potrošnje pojedinih droga kao okolinski čimbenici mogu posredno utjecati i na razvoj komorbiditeta kod ovisnosti i kao takve ih treba uzeti u obzir u pojedinačnom slučaju. Istraživanjem trauma u ranom djetinjstvu i uporabe kanabisa prije 17-te godine utvrđena je povezanost s pokušajima samoubojstva (Agrawal i Lynskey, 2014). Sljedeći 
primjer utjecaja okolinskih čimbenika odnosi se na istraživanje o shizofreniji i perzistirajućem halucinogenom perceptivnom poremećaju. Pri tome treba istaknuti kako se oba poremećaja pojavljuju u komorbiditetu s uporabom halucinogenih droga poput LSD-a. U tom pogledu u istraživanju Lev-Ran i sur. (2014) neki ispitanici sa shizofrenijom i halucinogenim poremećajem izvještavaju o sposobnosti prepoznavanja specifičnih znakova koji prethode pojavi perceptivnih distorzija (glasni zvukovi, boravak na tamnom mjestu itd.).

Istraživanjem utjecaja obiteljskih obilježja na pojavu dualnog poremećaja Kendler i suradnici (2003b) navode kako socijalni rizični čimbenici poput razorenih obitelji, slabog roditeljskog nadzora i niskog socioekonomskog statusa mogu prodonijeti pojavi komorbiditeta kod osoba s eksternaliziranim poremećajem u ponašanju. Aseltine, Gore i Colten (1998; prema Green i sur., 2012) izvještavaju kako niska razina obiteljske podrške razlikuje adolescente s komorbiditetom depresije i ovisnosti u odnosu na one koji samo zloupotrebljavaju droge ili imaju samo depresiju. Iz navedenog proizlazi kako adolescenti s komorbiditetom depresije i ovisnosti imaju značajno manje podržavajuće odnose s članovima obitelji u odnosu na one koji imaju samo depresiju ili samo konzumiraju droge. Nastavno, pokazalo se kako perzistirajući sukobi s članovima obitelji i vršnjacima također predstavljaju čimbenike koji razlikuju osobe koje imaju samo depresiju ili samo konzumiraju droge. Green i suradnici (2012) istraživanjem su identificirali dva čimbenika unutar obitelji - obiteljske konflikte i i nedostatak roditeljskog nadzora koji su pokazali relativno malu statističku značajnost u multivarijatnom modelu prilikom razlikovanja komorbiditeta ovisnosti u odnosu na ovisnost bez depresivnog poremećaja. Temeljem rezultata istraživanja isti autori sugeriraju kako ovisnosti vjerojatnije prethode raniji problemi u ponašanju, rani početak uporabe marihuane, akademski neuspjeh, napuštanje srednje škole i obiteljski čimbenici poput obiteljskih konflikata, siromaštva i roditelja s niskim stupnjem obrazovanja. U konačnici, svi ovi faktori u stjecaju predstavljaju prediktivne čimbenike ne samo za pojavu psihičkog poremećaja kod konzumenta droga (Green i sur., 2012), već općenito, generiraju i ulazak u ovisničku i/ili kriminalnu subkulturu i dugotrajno uzimanje droga. Može se ustvrditi kako okolinski čimbenici znatno doprinose razvoju komorbiditeta ovisnika i stoga se očekuje da se buduća istraživanja usmjere na proučavanje uloge određenih društvenih čimbenika u genezi ovog poremećaja.

Temeljem dosadašnjih spoznaja i rezultata istraživanja razvidno je da osobe s psihičkim poremećajima predstavljaju rizičnu skupinu za započinjanje uzimanja sredstava ovisnosti. Uz navedeno, kod njih postoji veća vjerojatnost da će u konačnici razviti i ovisnost. U tom pogledu, specifična težina bolesti osoba s komorbiditetom, za razliku od drugih s jednim dijagnosticiranim poremećajem, u pravilu se manifestira višestrukim negativnim ishodima koji podrazumijevaju neujednačenost u dijagnosticiranju, loše tretmanske ishode, tzv. psihijatrizaciju života, pridružene tjelesne bolesti te obiteljske i probleme u društvenoj integraciji (školovanje, zapošljavanje i sl.). Stoga će nastavno biti opisani najučestaliji psihički poremećaji u komorbiditetu s ovisnošću.

\section{Psihički poremećaji u komorbiditetu s ovisnošću}

\section{Depresija i ovisnost}

Depresija i ovisnost predstavljaju dva najučestalija poremećaja koji se pojavljuju u komorbiditetu, a njihova stopa prevalencije kreće se u rasponu od $12 \%$ do $80 \%$ (Torrens i sur., 2011). U 
svezi ovog komorbiditeta treba istaknuti činjenicu da se kod komorbiditeta veliki depresivni poremećaj češće definira kao primarni, odnosno neovisan poremećaj (Samet i sur., 2013; Blanco i sur., 2012). Navedeni podatak potvrđuju studije praćenja kod kojih je veliki udio osoba s komorbiditetom ovisnosti reklasificiran u novu skupinu kod koje je prisutan samo veliki depresivni poremećaj (Magidson i sur., 2013). Iz navedenog proizlazi da u slučaju komorbiditeta nakon nekog vremena veliki depresivni poremećaj kod osobe može postati dominantan i nastaviti egzistirati samostalno. U tom pogledu oba poremećaja imaju lošije izglede za napredak tijekom tretmana, pri čemu postoji veća vjerojatnost za nepoželjni smjer razvoja depresije (Torens i sur., 2005). Pritom valja istaknuti da je težina jednog poremećaja razmjerna težini drugog, stoga osobe s komorbiditetom trpe od više teških kliničkih stanja, lošije odgovaraju na tretmanske učinke i generalno imaju lošije prognoze za tretman oba poremećaja (Hasin i Grant, 2004). U svakom slučaju, nepoželjan smjer razvoja depresije može biti popraćen i nepoželjnim smjerom razvoja ovisnosti (Samet i sur., 2013). Nadalje, treba istaknuti da su kod osoba s ovom vrstom komorbiditeta zabilježene više stope pokušanih i dovršenih samoubojstava u odnosu na osobe sa samo jednim od pridruženih poremećaja (Blanco i sur., 2012), mogu razviti i druge medicinske i psihičke komorbiditete, manifestiraju i znatne psihosocijalne poteškoće te učestalije koriste usluge službi za klinički tretman, posjete hitne službe i hospitalizaciju na psihijatrijskim odjelima (Samet i sur, 2013).

\section{Anksiozni poremećaji i ovisnost}

Anksiozni poremećaji i njegove podvrste imaju prilično visoku stopu prevalencije kod ovisnika i to kod 35 \% ispitanika (Fatseas i sur., 2010). Međutim, uzročnost same povezanosti nije u potpunosti razjašnjena te se navodi da ona ovisi o vrsti konzumirane droge (npr. kokain ili kanabis) te o pripadajućim anksioznim poremećajima. Po pitanju vrste konzumirane droge u komorbiditetu s anksioznim poremećajima marihuana je na prvom mjestu s udjelom od $15 \%$, nakon čega slijede kokain i amfetamin s udjelom od oko $5 \%$, halucinogene droge $4 \%$ te sedativi s oko $3 \%$ (Conway i sur., 2006; prema Brady i sur., 2013). S druge strane, prema podvrsti anksioznih poremećaja, panični poremećaj i poslijetraumatski stresni poremećaj procjenjuju se kao najučestaliji, s prevalencijom od $1 \%$ do $10 \%$, odnosno do $30 \%$ (EMCDDA, 2015). Međutim, postupak dijagnosticiranja anksioznih poremećaja kod ovisnika ima određene poteškoće koje proizlaze iz utvrđivanja uzorka pojave anksioznih simptoma. Naime, oni se mogu pojaviti kao posljedica intoksikacije jednom ili kombinacijom više različitih droga ili kao posljedica simptoma apstinencijske krize. Kako bi se navedena problematika što učinkovitije riješila, važno je promatrati simptome koji se javljaju tijekom apstinencijske krize. Naime, anksiozne simptome možemo promatrati iz dvije perspektive (Brady i sur., 2013). Prva se odnosi na pojavu anksioznih simptoma kod osoba prije početka uporabe sredstava ovisnosti, kao i kod članova njene obitelji. Druga perspektiva u fokus stavlja pojedinca, naglašavajući prisutnost anksioznih simptoma nakon duljeg razdoblja apstinencije. U navedenim slučajevima zasigurno se može potvrditi prisutnost anksioznih poremećaja koji zahtijevaju liječenje. Uz navedeno, treba istaknuti kako povećana učestalosti uporabe kanabisa predstavlja snažan prediktor za pojavu anksioznosti i to u vidu paničnih napada. Također, kod redovnih konzumenata može doći do promjene u djelovanju samog kanabisa u tom pogledu da kanabis više nije u ulozi pokretača anksioznosti, već njegov učinak djeluje anksiolitički, umirujuće i zbog toga se anksioznost može smatrati predisponirajućim čimbenikom za početak uporabe kanabisa (Coscas i sur., 2013). 


\section{Psihotični poremećaji i ovisnost}

Specifičnot ove vrste komorbiditeta ogleda se u činjenici da osobe s psihotičnim poremećajima počinju uzimati različite nedopuštene tvari kako bi se mogli nositi sa simptomima psihoze. Kada dođe do razvoja komorbiditeta navedenih poremećaja, postoji veći rizik za hospitalizaciju, viša stopa smrtnostii viša razina deprivacije. Naime, komorbiditet psihotičnog poremećaja i ovisnosti zastupljen je s udjelom od 30 - 60 \% kod osoba sa shizofrenijom (Green, 2005), što dovodi do problema razlikovanja akutne shizofrene simptomatologije od psihoze inducirane uporabom tvari. Stoga kod dijagnostike valja voditi računa o tome da se na adekvatan način procijeni uzrok pojave pojedinih simptoma. Nadalje, komorbiditet shizofrenije i ovisnosti povezan je s povećanom stopom smrtnosti i lošijim tretmanskim ishodima u odnosu na isključivu ovisnost (EMCDDA, 2015). $\mathrm{U}$ tom pogledu potrebno je napomenuti da je ovisnost povezana s neusklađenim tretmanom oba poremećaja pri čemu dolazi do odgađanja liječenja shizofrenije. Međutim, smanjenjem uporabe tvari u svrhu zadržavanja u tretmanu posljedično dolazi do smanjenja ukupnih simptoma kod osoba s psihozom (Green, 2005; Gregg et al., 2007; San et al., 2007a; Schmidt, Hesse i Lykke 2011).

\section{Procjena psihičkih poremećaja kod ovisnika}

Procjena prisutnosti komorbiditeta psihičkih poremećaja kod ovisnika je zahtjevna. Prije svega, prilikom utvrđivanja komorbiditeta valja razumjeti i prepoznati razliku između očekivanih učinaka same droge (razlikovati posljedice intoksikacije) i simptoma apstinencijske krize. Također, postoji razlika između neovisnog psihičkog poremećaja i onog koji nastaje kao posljedica uzimanja droge. Različiti etiološki aspekti komorbiditeta uvjetuju i različite kliničke pravce razvoja poremećaja te tretmanske ishode (Torrens, Martin-Santos i Samet, 2006). Stoga kod dijagnosticiranja komorbiditeta postoje dvije poteškoće. Prva se odnosi na mogućnost da akutni ili kronični učinci konzumirane droge "prekriju“ ili prividno anuliraju simptome psihičkih poremećaja. Pri tome postoji problem utvrđivanja i razlikovanja primarnog nezavisnog poremećaja od posljedica uporabe droge. Druga teškoća vezana je uz činjenicu da psihička stanja predstavljaju sindrom (skup simptoma) neke bolesti, ali ne i samu bolest. U tom pogledu praktičari moraju koristiti dva najpoznatija i učinkovitija dijagnostička kriterija sadržanih u priručnicima bez kojih je praktični rad gotovo nezamisliv: Dijagnostički i statistički priručnik za duševne poremećaje — DSM-V (2013) i Međunarodna klasifikacija bolesti i srodnih zdravstvenih problema - MKB-10 (2012). Ovi dijagnostički priručnici su razvojem istraživanja i spoznaja o navedenom području tijekom vremena sumirali najnovija znanja specifična za određene poremećaje i određeno vremensko razdoblje. Temeljem navedenih priručnika i drugih važnih značajki za postavljanje dijagnoze dualnog poremećaja konstruirani su različiti instrumenti. Uzimajući u obzir njihova obilježja i dobre psihometrijske karakteristike ističu se tri instrumenta i jedan intervju. Prvi se odnosi na Instrument za procjenu dualne dijagnoze (Dual Diagnosis Screening Instrument - DDSI). On predstavlja važeći mjerni instrument namijenjen otkrivanju najčešćih i psihičkih poremećaja kod konzumenata droga poput depresije, manije, psihoze, panike, socijalne fobije, specifične fobije, ADHD-a i PTSP-a (Mestre-Pinto i sur., 2014). Njegova je prednost $u$ tome što ga mogu koristiti i drugi zdravstveni stručnjaci u području intervjuiranja $s$ obveznom obukom u trajanju od oko 90 minuta. Sadrži 64 čestice za čije je ispunjavanje potrebno samo $20-25$ minuta, a pokazao je i dobru prilagodljivost za primjenu u različitim okruženjima (bolničko i izvanbolničko liječenje) i to kod osoba koje konzumiraju različite vrste droga (opijate, 
alkohol, kokain, amfetamini, kanabis i MDMA). Ima vrlo dobre psihometrijske karakteristike (osjetljivost iznosi više od $85 \%$ kod svih dijagnoza).

Upitnik za psihijatrijsku dijagnostičku procjenu (Psychiatric Diagnostic Screening Questionnaire, PDSQ) je instrument za samoprocjenu 13 čestih poremećaja prema DSM-IV (2000). Upitnik sadrži 125 čestica, a potrebno vrijeme za popunjavanje je 20 minuta. Ispitivanja koja su testirala ovaj upitnik ukazuju da je riječ o solidnom testu i da su njegove mjerne karakteristike pouzdanost, visoka osjetljivost te specifične i prediktivne vrijednosti u odnosu na strukturirane kliničke intervjue (Perez Galvez i sur., 2010). Temeljem navedenih obilježja ovaj instrument se preporučuje za procjenu psihičkog zdravlja i uporabe sredstva ovisnosti već u primarnoj zdravstvenoj zaštiti.

Treći instrument je Obrazac za procjenu mentalnog zdravlja (Mental Health Screening Form). Riječ je o obrascu koji je razvijen u svrhu identificiranja komorbiditeta kod pojedinaca koji ulaze u tretman ovisnosti (Carroll i McGinley, 2001). Njegove prednosti su da primjena zahtijeva minimalan trening i za popunjavanje je potrebno izdvojiti 15 minuta, ("Da” i „Ne" odgovori). Instrument procjenjuje sljedeće kategorije poremećaja: shizofrenija, depresivni poremećaj, poslijetraumatski stresni poremećaj, fobije, povremeni eksplozivni poremećaj, sumanuti poremećaj, poremećaj spolnog identiteta, poremećaji hranjenja (bulimija i anoreksija), manične epizode, panični poremećaj, opsesivno-kompulzivni poremećaj, patološko kockanje, poremećaji učenja i mentalna retardacija. Naime, rezultati istraživanja podupiru primjenu instrumenta u radu s populacijom koja manifestira ovisnost (Ruiz i sur., 2009). U pogledu strukturiranih dijagnostičkih intervjua ističe se Provođenje intervjua za osobe $s$ alkoholom uzrokovanim poremećajem i za osobe s pridruženim psihičkim poremećajima (Alcohol Use Disorder and Associated Disabilities Interview Schedule - AUDADIS). On predstavlja intervju kojim se ispituje opća populacija, no može se koristiti u ispitivanjima populacije koja ima već dijagnosticiranu ovisnost o alkoholu i drogama (Hasin i sur., 1997). Mogu ga provoditi ne samo kliničari, već i drugi zdravstveni stručnjaci uz zadovoljavanje preduvjeta o završenoj obuci. Intervju sadrži module namijenjene mjerenju uporabe alkohola, duhana i droga, kao i depresije te antisocijalnog poremećaja ličnosti temeljem DSM-IV (2000) kriterija. Referentni okvir za postavljanje dijagnoze obuhvaća sva obilježja, probleme i druge segmente prisutne u životu pojedinca 12 mjeseci prije provođenja samog intervjua, kao i podatake o početku i remisiji svakog poremećaja te mjeri trajanje simptoma. Testiranjem psihometrijskih karakteristika i primjenom ponovljenog mjerenja za testiranje pouzdanosti, u kliničkim uvjetima dobivena je visoka pouzdanost za komorbiditet. Ponovljenim mjerenjima ovisnosti i droga AUDADIS-a ustanovljena je pouzdanost u rasponu od prosječne do izvrsne (Grant i sur., 1995, 2003).

\section{Tretmanske smjernice i modeli tretmana za osobe s komorbiditetom}

Kvaliteta sustava zdravstvene skrbi za osobe s dualnim poremećajem uglavnom se definira smjernicama za liječenje dualnog poremećaja. U tom pogledu Ured za suzbijanje zlouporabe droga Vlade Republike Hrvatske izdao je Smjernice za psihosocijalni tretman ovisnosti o drogama u zdravstvenom, socijalnom i zatvorskom sustavu (potpoglavlje Učinkovite psihosocijalne intervencije za osobe s psihijatrijskim komorbiditetom, 2014, 38). Važnost ovih smjernica očituje se u preporukama namijenjenima optimalizaciji skrbi o pacijentima, a utemeljene su na sustavnim izvješćima i dokazima te na procjeni koristi, odnosno štete alternativne skrbi. Naime, preporuke su usmjerene 
na pružanje pomoći stručnjacima i klijentima pri donošenju odluke o odabiru i primjeni odgovarajuće intervencije u specifičnim okolnostima. Stoga, smjernice uključuju skup preporuka i koraka koje valja slijediti kod provođenja intervencija, a njihov sadržaj utemeljen je na dostupnim istraživanjima (Ured za suzbijanje zlouporabe droga, 2014). Sukladno navedenom, u ovom dokumentu se navodi kako istovremeno postojanje ovisnosti i psihičkog poremećaja otežava ili onemogućuje liječenje osobe. Kako bi se izbjegli postojeći rizici i prevladali potencijalni negativni ishodi, NSW Health Guidelines (2008, prema Ured za suzbijanje zlouporabe droga, 2014) donose nekoliko ključnih intervencija koje treba primjenjivati kod osoba s komorbiditetom ovisnosti. Naime, ističe se važnost procjene vrste i stupnja psihičke bolesti i stanja uz ovisnost, nakon čega je potrebno potaknuti osobu na ostanak u tretmanu. Od najveće je važnosti raditi na povećanju motivacije i aktivnom sudjelovanju u tretmanu. Uz navedeno, potrebno je provoditi edukaciju stručnjaka s ciljem unaprjeđenja znanja o interakciji sredstva ovisnosti sa simptomima psihičke bolesti te se preporučuje provođenje integrativnog pristupa tretmanu u sklopu kojeg valja koristiti ili provoditi farmakološke i psihosocijalne intervencije.

Pregledom literature i intervjuiranjem osoba s komorbiditetom Ness, Borg i Davidson (2014) navode podržavajuće čimbenike, kao i prepreke za tretman i oporavak. U kontekstu podržavajućih čimbenika za oporavak ističe se potreba smislenog provođenja svakodnevnice, što uključuje strukturirano provođenje vremena i bavljenje sportskim aktivnostima uzimajući u obzir čime se, zapravo, klijent želi baviti za svoju dobrobit. Time se klijenti oslanjaju na vlastite snage, prihvaćanje vlastitog iskustva, orijentaciju i promišljanje o budućnosti, ponovno uspostavljanje socijalnog života i podržavajuće prijateljske odnose te preuzimanje odgovornosti za sebe i druge. Navedeni podržavajući čimbenici su, u suštini, sami po sebi razumljivi i prihvatljivi jer imaju univerzalni značaj u životu ljudi, neovisno o ovisnosti i povezanom psihičkom poremećaju. Također treba naglasiti dobrobit bavljenja fizičkim aktivnostima, osobito tijekom oporavka od ovisnosti kada organizam treba detoksikaciju kako bi se povratile sposobnosti koncentracije i provođenja aktivnog života. Istodobno, usmjerenost prema budućnosti i razmišljanje o njoj često može izazvati strah kod osoba s dualnom dijagnozom. Stoga treba sagledati vlastite mogućnosti, nanovo preispitati postoji li stvarna želja za poboljšanjem kojoj mogu pridonijeti pozitivni, podržavajući i prijateljski odnosi u društvenom životu klijenta. S druge strane, prepreke u postizanju tretmanskih ciljeva nažalost se nerijetko događaju u samom zdravstvenom sustavu. Naime, nedostatak razumijevanja, tolerancije i prilagodbe na recidiv od strane liječnika i terapeuta tijekom tretmana uvelike može demotivirati osobu. Na spomenuto se nadovezuje i problematika složenog i nekoordiniranog sustava pružanja pomoći i podrške koji je često prezahtjevan za klijente.

\section{Modeli tretmana za osobe s komorbiditetom}

U većini država pružanje zdravstvenih usluga i tretman mentalnog zdravlja za ovisnike često su razdvojeni. Ova odvojenost stvara poteškoće u osiguravanju optimalnog tretmana oba poremećaja (Ness, Borg i Davidson, 2014). Javljaju se i dvojbe vezane uz pouzdanost dijagnostike, odnosno nedovoljno kvalitetne procjene oba poremećaja, što posljedično utječe na kvalitetu i koordinaciju samog tretmana (Sacks i sur., 2013). Pored toga, karakteristike tretmanskih pristupa također mogu predstavljati problem, a odnose se na način provođenja tretmana te reguliranje i financijsku zahtjevnost tretmana (Burnam i Watkins, 2006). Iliceto i suradnici (2010) tvrde kako 
osobe s psihičkim poremećajima i povezanom ovisnošću nailaze na brojne poteškoće zbog toga što se ne uklapaju u uobičajene tretmanske i rehabilitacijske programe. Navedenu problematiku potvrđuju podaci Substance Abuse and Mental Health Services Administration (2011) iz SAD-a koji pokazuju da je samo $44 \%$ osoba u tretmanu za jedan od više komorbidnih poremećaja, dok je gotovo alarmantan podatak kako je samo 7 \% klijenata uključeno u tretman za oba poremećaja. Unatoč istaknutoj potrebi, teoretičari i praktičari do sada nisu postigli suglasje glede najučinkovitijih tretmanskih modela, bilo da je riječ o farmakološkom i/ili psihosocijalnom tretmanu. Stoga se može ustvrditi da je zdravstvena politika relativno neuspješna u pogledu kreiranja adekvatnih i svrhovitih tretmanskih smjernica za oba poremećaja, što predstavlja veliki izazov za donositelje političkih odluka, kliničare i profesionalce. Stoga, EMCDDA (2015) predstavlja tri modela tretmana: serijski, usporedni i integrirani model.

Uzastopni ili serijski model tretmana promiče stav o tome da prvo valja provoditi tretman za prvi ozbiljniji poremećaj, dok je drugi sekundaran i u prvom stadiju izvan tretmana dok se prvi ne stabilizira. Naime, u sklopu komorbiditeta ovisnosti i psihičkog poremećaja mreža pružatelja tretmanskih usluga je nezavisna i institucije djeluju odvojeno. Jedina poveznica između dva različita pružatelja tretmana je upućivanje pojedinca iz jedne institucije (vrste usluga) u drugu. Ako dođe do neusklađenosti ili nepovezanosti između dviju vrsta tretmana, povećava se rizik odustanka i prekida oba tretmana, što predstavlja golem neuspjeh i obeshrabruje klijenta u smislu povratka i nastavka liječenja. Drugi značajniji problem odnosi se na činjenicu da su komorbidni poremećaji u interakciji te pojedinačnim tretmanom svakog od njih dolazi do ograničavanja učinka cjelokupnog tretmana i njegovih ishoda. Naime, interakcija ovisnosti i psihičkog poremećaja objašnjava visoku stopu recidiva za oba poremećaja što ujedno dovodi do frustracije, kako kod provoditelja tretmana, tako i kod samih klijenata. Burnam i Watkins (2006) stoga zaključuju da uzastopni ili sekvencijalni model tretmana ne bi trebao biti primjenjivan u radu s dualnim poremećajem.

Drugi model je usporedni model tretmana koji podrazumijeva istodobni tretman oba problema, odnosno poremećaja i to kod dva specijalizirana, ali često odvojena pružatelja tretmanskih usluga. $U$ ovom slučaju prisutno je organizacijsko pitanje koje značajno utječe na kvalitetu suradnje pružatelja tretmanskih usluga. Navedeno može rezultirati upućivanjem klijenta u tretman samo jedne komorbidne dijagnoze ili zbog sudjelovanja u jednom tretmanu može biti isključen iz drugog. Nažalost, u toj situaciji osobe s komorbiditetom same preuzimaju težinu odgovornosti za odabir i ustrajnost u tretmanu (Burnam i Watkins, 2006). U konačnici, problemi s kojima se ovisnici često susreću uglavnom se odnose na učinkovitost dostupnih oblika podrške, nedostatak koordinacije pri određivanju nositelja tretmana, logističke probleme pristupanja lokaciji pružatelja usluga, stigmatizaciju i negativne stavove osoblja prema ovisnicima, ali i postojanje apriornog stava o kriminalnom ponašanju vezanom uz uporabu droga (Neale, Tompkins i Sheard, 2008).

Treći model je integrirani model tretmana koji se odnosi na istovremeni i integrirani tretman psihičkog poremećaja i ovisnosti (Drake, Wallach i McGovern, 2005). Ovaj model predviđa kreiranje tretmana oba poremećaja na način da se tretmanski programi provode istovremeno $i$ da ih vodi multidisciplinarni tim. Međutim, Burnam i Watkins (2006) upozoravaju kako nadilaženje tradicionalnih razlika u davanju tretmanskih usluga od strane različitih pružatelja usluga nije lako postići. Slijedom toga, potrebno je premostiti razlike u pristupu tretmanu te kreirati učinkovit i integrirani tretmanski sustav za osobe s komorbiditetom. lako je integrirani model bio predstavljen kao mjera 
za smanjivanje razlika i rizika za odustajanje te smanjenje dupliciranja tretmanskih koraka, u EU za to ne postoje dokazi. Većina istraživanja o integriranom tretmanu provedena je na uzorku klijenata s teškim psihičkim poremećajem i ovisnošću (Craig i sur., 2008). Nedavno istraživanje provedeno u Norveškoj pokazalo je kako integrirani tretman doprinosi povećanju motivacije za sudjelovanjem u tretmanu kod osoba u izvanbolničkom liječenju s komorbiditetom depresije ili anksioznosti i ovisnosti (Wüsthoff i sur., 2014). U Finskoj, Italiji, Nizozemskoj, Norveškoj i Španjolskoj postoje specijalizirane jedinice za stacionarno liječenje osoba s akutnim dualnim poremećajem, stambene zajednice za "dualce" te programi koji se provode u centrima u zajednici. Navedeni primjeri ukazuju na korake koji se poduzimaju kako bi u praksi zaživio integrirani tretman (EMCDDA, 2015). Evidentno je da sintagma „integrirani tretman" zvuči obećavajuće, međutim, podrazumijeva uvjete koje je teško postići. Istraživanja o relevantnosti ove vrste tretmana uglavnom dolaze izvan Europe. U tom smislu Australian Institute of Health and Welfare (2005) ističe kako nalazi o pristupima liječenju i skrbi o osobama s komorbiditetom nisu sustavni, a podaci nisu rigorozno evaluirani. Ovi problemi, između ostalog, proizlaze iz teškoća praćenja i ispitivanja osoba s komorbiditetom jer je riječ o osobama koje su nerijetko nedostupne zbog ovisničkog stihijskog (nestrukturiranog) načina života. S druge strane, Drake i sur. (1998) navode da primjenom integriranog tretmana u liječenju osoba s komorbiditetom ovisnosti i psihičkog poremećaja dolazi do pozitivnih pomaka za oba poremećaja. U konačnici, ipak, treba konstatirati kako ubuduće treba težiti tome da se ispoštuju uvjeti za provođenje integriranog tretmana u praksi i nastaviti istraživanja o njegovoj učinkovitosti.

\section{Zaključak}

Terminološka određenja, pristupi, utvrđivanje etiologije i drugi važni elementi vezani uz komorbiditet razvijali su se tijekom vremena usporedno s napretkom u istraživačkim metodama. Početni problemi vezani uz njegovo određenje riješeni su utvrđivanjem međunarodno priznatih definicija i uvođenjem pojma komorbiditeta ili dualnog poremećaja od strane Svjetske zdravstvene organizacije (WHO, 2010) i Europskog centra za praćenje droga i ovisnosti o drogama (EMCDDA, 2015).

Postoji visok stupanj prevalencije komorbidnih dijagnoza kod ovisnika, pri čemu su osobito zabrinjavajući oni vezani uz marginalne skupine (Casares-Lopez i sur., 2011; Aichhorn i sur., 2008). One obuhvaćaju osobe mlađe životne dobi, zatvorsku populaciju, ovisnike koji ne traže ili nisu uključeni u bilo koji oblik tretmana, kao i beskućnike kao posebnu kategoriju. $U$ tom pogledu ističe se potreba za efikasnijim otkrivanjem ovih slučajeva, olakšanim uključivanjem u tretman (dostupnosti tretmana), kao i za jačanjem motivacije za zadržavanjem u tretmanu. Teškoće vezane uz učinkovito otkrivanje povezane su s nedostatkom općeprihvaćenog stajališta o uzrocima komorbiditeta.

Pregledom epidemioloških podataka proizlazi kako su najzastupljeniji psihički poremećaji u komorbiditetu s ovisnošću depresivni i anksiozni poremećaj, nakon čega slijede poremećaji ličnosti i psihotični poremećaj (EMCDDA, 2013, 2015). Evidentne su teškoće vezane uz učinkovito otkrivanje problema, a povezane su s nedostatkom općeprihvaćenog stajališta o uzrocima dualnog poremećaja. U tom pogledu, otežano je i provođenje metodološki ujednačenih i ka određenim ciljnim populacijama usmjerenih istraživanja zbog nesuglasja glede uzroka i teške dostupnosti ciljne populacije. Unatoč tome, podaci o rizičnim čimbenicima na temelju kojih se prepoznaju rizične 
skupine pomažu u procesu detekcije dualnog poremećaja. U tom pogledu, genetski rizični čimbenici imaju znatan utjecaj na pojavu komorbiditeta, no, prilikom njihova proučavanja potrebno je uzeti u obzir i druge osobne i okolinske čimbenike (Cantao i sur., 2015). Ovisnosti najčešće prethode raniji problemi u ponašanju, rani početak uporabe marihuane, akademski neuspjeh, napuštanje srednje škole i obiteljski čimbenici poput obiteljskih konflikata, siromaštva i roditelja s niskim stupnjem obrazovanja, na što se nadovezuju i socijalni rizični čimbenici poput razorenih obitelji, slabog roditeljskog nadzora i niskog socioekonomskog statusa (Green i sur., 2012, Kendler i sur., 2003b). U svrhu što kvalitetnije procjene prisutnosti dualnog poremećaja razvijeni su razni instrumenti, pri čemu su istaknuti oni s povoljnim mjernim karakteritikama, no, istovremeno treba voditi računa o zahtjevima koje pojedni instrument postavlja pred istraživača/kliničara.

U pogledu tretmana komorbiditeta ovisnosti i psihičkih poremećaja teoretičari i praktičari do danas se nisu usuglasili u pogledu najučinkovitijih tretmanskih modela, bilo da je riječ o farmakološkom i/ili psihosocijalnom tretmanu. Međutim, dosadašnja istraživanja preporučuju provođenje integrativnog pristupa tretmanu koji podrazumijeva provođenje farmakoloških i psihosocijalnih intervencija. Temeljem dosadašnjih spoznaja integrirani model tretmana objedinjuje tretman oba poremećaja, a tretmanski programi izvode se istovremeno uz sudjelovanje multidisciplinarnog tima. Njegovom primjenom dobiveni su pozitivni pomaci kod oba poremećaja te je potrebno provoditi daljnja istraživanja vezana uz kvalitetu tretmanskih ishoda. U konačnici, integrirani model tretmana predstavlja optimalan model dobre prakse kojem bi trebalo težiti u kontekstu pružanja tretmanskih usluga za liječenje dualnog poremećaja. U tom smislu od iznimne je važnosti kvaliteta procjene vrste i stupnja psihičke bolesti i stanja uz ovisnost pri čemu u procesu procjene uz psihijatre trebaju sudjelovati i drugi stručnjaci poput socijalnih pedagoga, psihologa i slično. Također je poželjno da interdisciplinarni tim stručnjaka radi istovremeno i na povećanju aktivnog sudjelovanja klijenta u tretmanu te jačanju motivacije za ostanak i zadržavanje u tretmanu. $U$ ovom kontekstu potrebno je usmjeriti se i na edukaciju šire populacije u cilju povećanja svjesnosti o zastupljenosti i problematici dualnog poremećaja u svrhu programiranja i provođenja što kvalitetnijih i učinkovitijih tretmanskih usluga, a koje sukladno težini i zastupljenosti ovog problema trebaju predstavljati imperativ današnjeg društva.

\section{Literatura}

Agrawal, A. i Lynskey, M.T. (2014). Cannabis controversies: how genetics can inform the study of comorbidity. Society for the Study of Addiction, 109, 360-370.

Aichhorn, W., Santeler, S., Stelzig-Scholer, R., Kemmler, G., Steinmayr-Gensluckner, M. i Hinterhuber, H. (2008). Prevalence of psychiatric disorders among homeless adolescents. Neuropsychiatrie: Klinik, Diagnostik, Therapie und Rehabilitation, 22 (3), 180-188.

American Psychiatric Association (2000). Diagnostic and Statistical Manual of Mental Disorders, Fourth edition. American Psychiatric Association. Washington, D.C.

American Psychiatric Association (2013). Diagnostic and Statistical Manual of Mental Disorders, Fifth edition. American Psychiatric Association. Arlington.

American Psychiatric Association (2016). Supplement to Diagnostic and Statistical Manual of Mental Disorders, Fifth edition. American Psychiatric Association. Arlington. 
Antičević, V., Jokić-Begić, N. i Britvić, D. (2012). Spolne razlike u osobinama ličnosti ovisnika o heroinu i konzumenata marihuane na Eysenckovom upitniku ličnosti (EPQ). Društvena istraživanja, 115 (1), 203-218.

Australian Institute of Health and Welfare (2005). National Comorbidity Initiative: A review of data collections relating to people with coexisting substance use and mental health disorders. Australian Institute of Health and Welfare. Canberra.

Baldacchino, A., Blair, H., Scherbaum, N., Grosse-Vehne, E., Riglietta, M., Tidone, L., Criaco, C., Marelli, M.C., Sommer, B., Tan, L., Little, H. i Ghodse, H. (2009). Drugs and psychosis project: a multi-centre European study on comorbidity. Drug and Alcohol Rewiev, 28 (4), 379-389.

Ball, S.A. (2005). Personality traits, problems and disorders: Clinical applications to substance use disorders. Journal of Research in Personality, 39, 84-102.

Becker, J.B. i Hu, M. (2008). Sex Differences in Drug Abuse. Frontiers in Neuroendocrinology, 29 (1), 36-47.

Bernacer, J., Corlett, P.R., Ramachandra, P., McFarlane, B., Turner, D.C., Clark, L., Robbinson, T.W., Fletcher, P.C. i Murray, G.K. (2013). Methamphetamine-induced disruption of frontostriatal reward learning signals: relation to psychotic symptoms. American Journal of Psychiatry, 170 (11), 1326-1334.

Blanco, C., Alegria, A.A., Liu, S.-M., Secades-Villa, R., Sugaya, L., Davies, C. i Nunes, E.V. (2012). Differences among major depressive disorder with and without co-occurring substance use disorders and substance-induced depressive disorder: results from the National Epidemiologic Survey on Alcohol and Related Conditions. The Journal of Clinical Psychiatry, 73 (6), 865-873.

Bossong, M.G., Jager, G., Bhattacharyya, S. i Allen, P. (2014). Acute and non-acute effects of cannabis on human memory function: a critical review of neroimaging studies. Current pharmaceutical design, 20 (13), 2114-2125.

Brady, K.T., Grice, D.E., Dustan, L. i Randall, C. (1993). Gender Differences in Substance Use Disorders. American Journal of Psychiatry, 150, 1707-1711.

Brady, K.T. i Sinha, R. (2005). Co-occuring mental and substance use disorders: the neurobiological effects of chronic stress. American Journal of Psychiatry, 162 (8), 1483-1493.

Brady, K.T., Haynes, L.F., Hartwell, K.J. i Killeen, T.K. (2013). Substance Use Disorders and Anxiety: A Treatment Challenge for Social Workers. Social Work in Public Health, 28, 407-423.

Burnam, M.A. i Watkins, K.E. (2006). Substance abuse with mental disorders: specialized public systems and integrated care. Health Affairs, 25 (3), 648-658.

Butorac, K. (2010). Neka obilježja osobnosti kao prediktivni čimbenici zlouporabe i ovisnosti o drogama i alkoholu. Kriminologija i socijalna integracija, 18 (1), 79-98.

Cantao L., Fonseca L.L.K., Silva T.I.M., Oliveira M., Oliveira V.C. i Machado R.M. (2015). Socio-demographic and clinical profile of elderly people with depression and the use of psychoactive drugs. Revista Rene, 16 (3), 355-362.

Carroll, J.F.X. i McGinley, J.J. (2001). A screening form of identifying mental health problems in alcohol/other drug dependent persons. Alcoholism Treatment Quarterly, 19 (4), 33-47.

Casares-Lopez, M.J., Gonzalez-Menendez, A., Bobes-Bascaran, M.T., Secades, R., Martinez-Cordero, A. i Bobes, J. (2011). Need for the assessment of dual diagnosis in prison. Adicciones, 23 (1), 37-44. 
Chaloupka, F.J. i Lixuthai, A. (1997). Do youths substitute alcohol and marijuana? Some econometric evidence. Eastern Economic Journal, 23, 253-276.

Combaluzier, S., Gouvernet, B. i Bernoussi, A. (2009). Impact of personality disorders in a sample of 212 homeless drug usere. Lecephale, 35 (5), 448-453.

Coscas, S., Benyamina, A., Reynauld, M i Karila, L. (2013). Psychiatric complitaions of cannabis use. La Revue Du Praticien, 63 (10), 1426-128.

Craig, T.K.J., Johnson, S., McCrone, P., Afuwape, S., Hughes, E., Gournay, K., White, I., Wanigaratne, S., Leese, M. i Thornicroft, G. (2008). Integrated care for co-occuring disorders: Psychiatric symptoms, social functioning, and service costs at 18 months. Psychiatruc Services, 59 (3), 276-282.

Drake, R.E., Mercer-McFadden, C., Mueser, K.T., McHugo, G.J., Bond, G.R. (1998). Review of integrated mental health and substance abuse treatment for patients with dual disorders. Schizophrenia Bulletin, 24 (4), 589-608.

Drake, R.E. i Wallach, M.A. (2000). Dual diagnosis: 15 years of progress. Psychiatric services, 51 (9), 1126-1129.

Drake, R.E., Wallach, M.A. i McGovern, M.P. (2005). Future directions in preventing relapse to substance abuse among clients with severe mental illnesses. Psychiatric Services, 56 (10), 1297-1302.

European Monitoring Centre for Drugs and Drug Addiction (2013). Co-morbid substance use and mental disorders in Europe: a review of the data. Publications Office of the European Union. Luxembourg.

European Monitoring Centre for Drugs and Drug Addiction (2015). Comorbidity of substance use and mental disorders in Europe. Publications Office of the European Union. Luxemburg.

Europski centar za praćenje droga i ovisnosti o drogama (2017). Europsko izvješće o drogama: trendovi i razvoj. Ured za publikacije Europske unije. Luksemburg.

Fatseas, M., Denis, C., Lavie, E. i Auriacombe, M. (2010). Relationship between anxiety disorders and opiate dependence. A systematic review of the literature. Implications for diagnosis and treatment. Journal of Substance Abuse Treatment, 38 (3), 220-230.

Grant, B.F., Harford, T.C., Dawson, D.A, Chou, P.S. i Pickering, R.P. (1995). The Alcohol Use Disorder and Associated Disabilities Interview Schedule (AUDADIS): reliability of alcohol and drug modules in a general population sample. Drug and Alcohol Dependence, 39 (1), 37-44.

Grant, B.F., Dawson, D.A., Stinson, F.S., Chou, P.S., Kay, W. I Pickering, R. (2003). The Alcohol Use Disorder and Associated Disabilities Interview Schedule-IV (AUDADIS-IV): reliability of alcohol consumption, tobacco use, family hisotry of depression and psychiatric diagnostic modules in a general population sample. Drug and Alcohol Dependence, 71 (1), 7-16.

Green, A.I. (2005). Schizophrenia and comorbid substance use disorder: effects of antipsychotics. The Journal of Clinical Psychiatry, 66 (6), 21-26.

Green, K.M., Zabrak, K.A., Fothergill, K.E., Robertson, J.A. i Ensminger, M.E. (2012). Childhood and Adolescent Risk Factors for Comorbid Depression and Substance Use Disorders in Adulthood. Addictive Behaviors, 37 (11), 1240-1247. 
Hasin, D., Carpenter, K.M., McCloud, S., Smith, M. i Grant, B.F. (1997). The alcohol use disorder and associated disabilities interview schedule (AUDADIS): reliability of alcohol and drug modules in a clinical sample. Drug and Alcohol Dependence, 44 (2-3), 133-141.

Hasin, D.S. i Grant, B.F. (2004). The co-occurence of DSM-IV alcohol abuse in DSM-IV alcohol dependence: results of the National Epidemiological Survey on Alcohol and Related Conditions on heterogeneity that differ by population subgroup. Archives of General Psychiatry, 61 (9), 891-896.

Hermle, L., Szlak-Rubin, R., Täschner, K.L., Peukert, P. i Batra, A. (2013). Substanzbezogene Störungen: häufigkeit bei Patienten mit schizophrenen oder affektiven Störungsbildern. Der Nervenartz, 84 (3), 315-325.

Hrvatski zavod za javno zdravstvo (2012). Međunarodna klasifikacija bolesti i srodnih zdravstvenih problema MKB - 10, Deseta revizija, svezak 1. - drugo izdanje. Medicinska naklada. Zagreb.

Iliceto, P., Pompili, M., Girardi, P., Lester, D., Vincenti, C., Rihmer, Z., Tatarelli, R., Akiskal, H.S. (2010). Hopelessness, Temperament, and Health Perception in Heroin Addicts. Journal of Addictive Diseases, 29, 352-358.

Kendler, K.S., Jacobson, K.C., Prescott, C.A. i Neale, M.C. (2003a). Specificity of Genetic and Environmental Risk Factors for Use and Abuse/Dependence of Cannabis, Cocaine, Hallucinogens, Sedatives, Stimulants, and Opiates in Male Twins. The American journal of psychiatry, 160 (4), 687-695.

Kendler, K.S., Prescott, C.A., Myers, J., i Neale, M.C. (2003b). The Structure of Genetic and Environmental Risk Factors for Common Psychiatric and Substance Use Disorders in Men and Women. Archives of General Psychiatry, 60, 929-937.

Kenkel, D., Mathios, A.D. i Pacula, R.L. (2001). Economics of youth drug use, addiction and gateway effects. Addiction, 96 (1), 151-164.

Khantzian, E.J. (1985). The self-medication hypotesis of addictive disorders: focus on heroin and cocaine dependence. American Journal of Psychiatry, 142 (11), 1259-1264.

Kreek, M.J., Nielsen, D.A., Butelman, E.R. i LaForge, K.S. (2005). Genetic influences on impulsivity, risk taking, stress responsivity and vulnerability to drug abuse and addiction. Nature neuroscience, 8 (11), 1450-1457.

Leray, E., Camara, A., Drapier, D., Riou, F., Bougeant, N., Pelissolo, A., Lloyd, K.R., Bellamy, V., Roelandt, J.L. i Millet, B. (2011). Prevalence, characteristics and comorbidities of anxiety disorders in France: results from the "Mental Health in General Population" survey (MHGP). European Psychiatry, 26 (6), 339-345.

Lev-Ran, S., Feingold, D., Frenkel, A. i Lerner, A.G. (2014). Clinical Characteristics of Individuals With Schizophrenia and Hallucinogen Persisting Perception Disorder: A Preliminary Investigation. Journal of dual diagnosis, 10 (2), 79-83.

Magidson, J.F., Wang, S., Lejuez, C.W., Iza, M. i Blanco, C. (2013). Prospective study of substance-induced and independent major depressive disorder among individuals with substance use disorders in a nationally representative samle. Depression and Anxiety, 30 (6), 538-545.

Mestre-Pinto, J.I., Domingo-Salvany, A., Martin-santos, R. i Torrens, M. (2014). Dual diagnosis screening interview to identify psychiatric comorbidity in substance users: development and validation of a brief instrument. European Addiction Research, 20 (1), 41-48. 
Moeller, F.G., Barratt, E.S., Doughtery, D.M., Schmitz, J.M. i Swann, A.C. (2001). Psychiatric aspects of impulsivity. American Journal of Psychiatry, 158 (11), 1783-1793.

Neale, J., Tompkins, C. i Sheard, L. (2008). Barriers to accessing generic health and social care services: a qualitative study of injecting drug users. Health \& Social Care in the Community, 16 (2), 147-154.

Ness, O., Borg, M. i Davidson, L. (2014). Facilitators and barriers in dual recovery: a literature review of first-person perspectives. Advances in Dual Diagnosis, 7 (3), 107-117.

Pacula, R.L. (1998). Does increasing the beer tax reduce marijuana consumption? Journal of health economics, 17 (5), 557-585.

Palijan, T.Z., Muzinić, L. i Radeljak, S. (2009). Psychiatric comorbidity in forensic psychiatry. Psychiatria Danubina, 21 (3), 429-436.

Perez Galvez, B., Garcia Fernandez, L., de Vincente Manzanaro, M.P. i Oliveras Valenzuela, M.A. (2010). Validation of the Psychiatric Diagnostic Screening Questionnaire (PDSQ) in Spanish sample of alcoholic patients. Addicciones, 22 (3), 199-205.

Radhakrishnan, R., Wilkinson, S.T. i D'Suoza, D.C. (2014). Gone to pot: a review of the association between cannabis and pshychosis. Frontiers in Psychiatry, 5 (54), 1-24.

Rodriguez-Llera, M.C., Domingo-Salvany, A., Brugal, M.T., Sanchez-Niubo, A. i Torrens, M. (2006). Psychitric comorbidity in young heroin users. Drug and Alcohol Dependence, 84 (1), 48-55.

Ruiz, M.A., Peters, R.H., Sanchez, G.M. i Bates, J.P. (2009). Psychometricproperties of the Mental Health Screening form IIIwithin a metropolitan jail. Criminal Justice and Behavior, 36 (6), 607-619.

Sacks, S., Chaple, M., Sirikantraporn, J., Sacks, J.Y., Knickman, J. i Martinez, J. (2013). Improving the capability to provide integrated mental health and substance abuse services in a state system of outpatient care. Journal of Substance Abuse Treatment, 44 (5), 488-493.

Samet, S., Fenton, M.C., Nunes, E., Greenstein, E., Aharonovich, E. i Hasin, D. (2013). Effects of independent and substance-induced major depressive disorder on remission and relapse of alcohol, cocaine and heroine dependence. Addiciton, 108 (1), 115-123.

Schmidt, L.M., Hesse, M. i Lykke, J. (2011). The impact of substance use disorders on the course of schizophrenia-a 15-years follow-up study: dual diagnosis over 15 years. Schizophrenia Research, 130 (1-3), 228-233.

Sofuoglu, M., DeVito, E.E., Waters, A.J. i Carroll, K.M. (2013). Cognitive Enhancement as a Treatment for Drug Addictions. Neuropharmacology, 64 (1), 452-463.

Sofuoglu, M., DeVito, E.E., Waters, A.J. i Carroll, K.M. (2016). Cognitive Function as a Transdiagnostic Treatme Target in Stimulant Use Disorders. Journal of dual diagnosis, 12 (1), 90-106.

Substance Abuse and Mental Health Services Administration (2011). Results from the 2010 National Survey on Drug Use and Health: Summary of National Findings. Preuzeto shttps://www. samhsa.gov/data/sites/default/files/NSDUHNationalFindingsResults2010-web/2k10ResultsRev/NSDUHresultsRev2010.pdf. (29. 6. 2017.)

Torrens, M., Fonseca, F., Mateu, G. i Farre, M. (2005). Efficacy of antidepressants in substance use disorders with and without comorbid depression: A systematicreview and meta-analysis. Drug and Alcohol Dependence, 78 (1), 1-22. 
Torrens, M., Martin-Santos, R. i Samet, S. (2006). Importance of clinical diagnoses for comorbidity studies in substance use disorders. Neurotoxicity Research, 10 (3-4), 253-261.

Torrens, M., Martinez-Sanvisens, D., Martinez-Riera, R., Bulbena, A., Szerman, N. i Ruiz, P, (2011). Dual diagnosis: Focusing on depression and recomendation fot treatment. Addictive Disorders \& Their Treatment, 10 (2), 50-59.

Ured za suzbijanje zlouporabe droga (2014). Smjernice za psihosocijalni tretman ovisnosti o drogama u zdravstvenom, socijalnom i zatvorskom sustavu. Vlada Republike Hrvatske. Zagreb.

Valderas, J.M., Starfield, B., Sibbald, B., Salisbury, C. i Roland, M. (2009). Defining Comorbidity: Implications for Understanding Health and Health Services. Annals of family medicine, 7 (4), 357-363.

Van Ours, J.C., Williams, J., Fergusson, D. i Horwood, L.J. (2013). Cannabis use and suicidal ideation. Journal of Health Economic, 32 (3), 524-537.

Wilsey, B.L., Fishermen, S.M., Tsodikov, A., Ogden, C., Symreng, I. i Ernst, A. (2008). Psychological Comorbidities Predicting Prescription Opioid Abuse among Patients in Chronic Pain Presenting to the Emergency Department. Pain Medicine, 9 (8), 1107-1117.

Wilson, G.T. (1987). Cognitive Processes in Addiction. British Journal of Addiction, 82 (4), 343-353.

Wüsthoff, L.E., Waal, H. I Grawe, R.W. (2014). The effectiveness of integrated tretament in patients with substance use disorders co-occurring with anxiety and/or depression - a group randomized trial. BMC Psychiatry, 14, 67.

Zammit, S., Owen, M.J., Evans, J., Heron, J. i Lewiv, G. (2011). Cannabis, COMT and psychotic experiences. The British journal of pscyhiatry: the journal of mental science, 199 (5), 380-385. 


\section{Comorbidity in addicts and treatment interventions}

\section{Summary}

Illegal drug abuse, in addition to excessive use of legally prescribed medications for treating mental disorders, lead to harmful consequences associated with severe health issues which raise a crucial question of national and international politics of combating psychoactive substance abuse. Therefore, concurrent substance-related disorders and mental illnessess often result in a severe clinical condition and associated social difficulties in various aspects of a person's everyday life. Consequently, careful consideration of such problems and addressing them is imperative. Given the insufficient attention and lack of both foreign and especially national sustained research on the topic, as well as generally accepted views of scientists and experts regarding patterns, etiology, diagnostic instruments and models of good practice in the treatment of comorbidity, this paper aims to provide an integrated overview of the current research results with critical review and recommendations regarding weaknesses and possibilities of the various treatment systems for addicts with comorbid disorders. Further to other related issues, this paper considers causal relations between psychological disorders, and disorders caused by drug abuse by means of risk factor analysis. The paper consists of the analysis of previous research pertaining to dual disorders across the European Union and beyond. The collected data indicate a considerable presence of comorbidity in the addict population, especially within marginal groups, as well as the importance of the overall evaluation of biopsychosocial characteristics of patients under treatment. Regarding the comorbidity treatment, theoreticians and practitioners have not reached consensus on the models of good practice yet related to either pharmacological or/ and psychosocial treatment. However, recent researches and understanding indicate the necessity of implementing an integrative approach to the treatment within which both pharmacological and psychosocial interventions should be used. Considering the fact that overall knowledge of comorbidity in addicts are insufficient, in Croatia they almost do not exist particularly, hence there is a necessity for further investigation in this area for the sake of implementation of the already existing preventive and treatment guidelines.

Keywords: comorbidity, risk factors, diagnostic instruments, treatment models

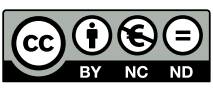

Međunarodna licenca / International License:

Creative Commons Attribution-NonCommercial-NoDerivatives 4.0. 